\title{
Effect of V-Ti on the Microstructure and Abrasive Wear Behavior of 6CrC Cast Steel Mill Balls
}

\author{
S. I. Maldonado-Ruiz ${ }^{*}$, P. Orozco-González ${ }^{1}$, V. H. Baltazar-Hernández ${ }^{1}$, \\ A. Bedolla-Jacuinde ${ }^{2}$, M. A. L. Hernández-Rodríguez ${ }^{3}$ \\ ${ }^{1}$ Unidad Académica de Ingeniería, Universidad Autónoma de Zacatecas, Zacatecas, México \\ ${ }^{2}$ Instituto de Investigaciones Metalúrgicas, Universidad Michoacana, Morelia, México \\ ${ }^{3}$ Universidad Autónoma de Nuevo León, Monterrey, México \\ Email: smald@uaz.edu.mx
}

Received 16 May 2014; revised 1 July 2014; accepted 22 July 2014

Copyright (C) 2014 by authors and Scientific Research Publishing Inc.

This work is licensed under the Creative Commons Attribution International License (CC BY). http://creativecommons.org/licenses/by/4.0/

(c) (i) Open Access

\begin{abstract}
Iron-chromium cast alloys are basically abrasive wear resistant materials particularly employed in mining industry; these alloys are often utilized in the manufacture of milling balls. In particular, high $\mathrm{Cr}$ and high $\mathrm{C}$ cast alloys have been subjected of significant research; for instance, most reports have been addressed on analyzing the relation between microstructure and the abrasive wear behavior; however, there exist a reduced number of reports on relatively low $\mathrm{Cr}$ and low $\mathrm{C}$ cast alloys. In this research, five low $\mathrm{Cr}$ cast steels containing additions of $\mathrm{V}$ and $\mathrm{Ti}$ were melted in an open atmosphere induction furnace. Comparisons on the morphology, size, type and distribution of carbides were carried through optical microscopy, SEM and XRD. Hardness testing was employed at room temperature with the purpose of correlate to wear behavior. A laboratory pilotplant ball-mill set with a batch of ore was utilized in order to evaluate the abrasive wear resistance. According to microstructure observations, a martensitic primary matrix was revealed in all specimens. The fraction of $M_{7} C_{3}$ and $M_{3} C$ interdendritic eutectic carbides varied according to alloying level. Further results indicated that variations in the shape and size of $M_{7} C_{3}$ and $M_{3} C$ along with the presence of $\mathrm{V}$ and $\mathrm{Ti}$ carbides influenced on the abrasive wear behavior of low $\mathrm{Cr}$ cast steel mill balls.
\end{abstract}

\section{Keywords}

Wear-Resistance, Grinding-Media, Cr-C Cast-Steel

\footnotetext{
${ }^{*}$ Corresponding author.
}

How to cite this paper: Maldonado-Ruiz, S.I., et al. (2014) Effect of V-Ti on the Microstructure and Abrasive Wear Behavior of $6 \mathrm{CrC}$ Cast Steel Mill Balls. Journal of Minerals and Materials Characterization and Engineering, 2, 383-391. 


\section{Introduction}

White cast iron is widely utilized in applications that require resistance to wear [1] [2]. White cast iron is extensively used in ore processing, mining, metallurgy and energy industries [3]-[6]. In particular, iron-chromium white cast irons (C-Cr-Fe) are specific groups of materials characterized as highly resistant to abrasive wear [7] [8]. Hence, there is a type of iron-chromium cast alloys which are often utilized in the manufacture of milling balls. Owe to milling ball application in ore grinding; the ball surface is exposed to different abrasive mediums like: silica (quartz), corundum, feldspar, basalts and other mineral particles [1].

Iron chromium cast irons are based on the $\mathrm{C}$-Cr-Fe diagram as it shows the phase relationships in the Fe-rich corner [9]. It is worth noting that these cast irons are comprised of iron-chromium carbides [10] (i.e. $\mathrm{M}_{3} \mathrm{C}, \mathrm{M}_{7} \mathrm{C}_{3}$ ) embedded into an iron matrix [6] [11]-[13]; such carbides are favored with presence of high carbon content [9]. Figure 1 shows the Fe-rich corner of the metastable C-Cr-Fe liquidous diagram [9] along with superimposed areas (shadow regions); it is important to mention that highlighted areas indicate these C-Cr-Fe alloys are being subject to extensive research [7] [14].

In most cases, iron-chromium cast irons are comprised of high carbon content and high chromium along with small amounts of molybdenum, nickel, vanadium, titanium, cupper, niobium, tungsten, and boron [15]. It has been reported that high chromium and carbon cast irons are extremely abrasion resistant owe to their carbide content and their orientation with respect to the wear surface played an important role in the wear behavior [16] [17]. A primary network of $\mathrm{M}_{7} \mathrm{C}_{3}$ surrounded by an austenitic matrix and eutectic carbides, influenced on the wear mechanism in high $\mathrm{C}$ and $\mathrm{Cr}$ cast alloys [18]. Further, improved wear resistance has been reported if adding Mo, $\mathrm{V}$ and $\mathrm{Ti}$, which in turn, has been related to the fine distribution of the eutectic aggregates [19]. Although there are a large number of reports regarding to abrasive wear of high-chromium cast irons; few reports are encountered having reduced amount of $\mathrm{C}$ and $\mathrm{Cr}$ when combined with a varied elements such $\mathrm{V}$-Ti and their effects on the abrasive wear resistance.

This work aims on evaluating the microstructure and the abrasive wear resistance of low chromium cast steel containing varied amounts of $\mathrm{V}$ and Ti by employing a small-scale pilot-plant mill.

\section{Experimental Procedure}

Five different selected cast alloys were used in this research. The selected cast alloys resulted from analysis of previous studies [18] [19] as well as from a split-plot experimental design of trial [20]. The whole batch of cast alloys were melted in an open atmosphere induction furnace having a hollow capacity of $15 \mathrm{~kg}$ per batch, and

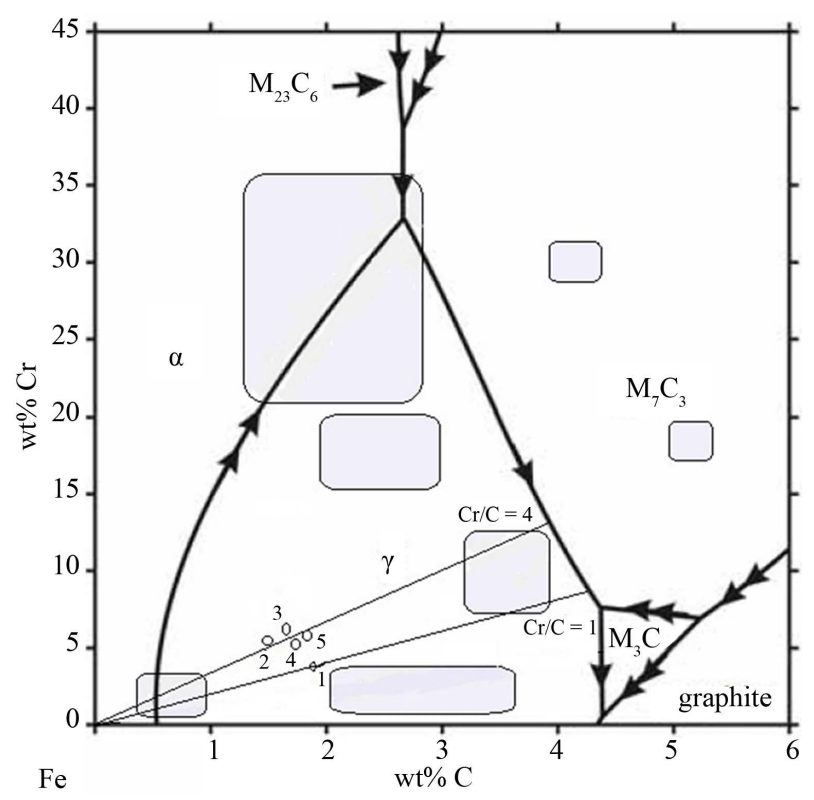

Figure 1. C-Cr-Fe-rich corner diagram, (the sign indicates the selected analyzed in this work, along with previous studies). 
poured into a sand mold.

The chemical composition of all alloys is listed in Table 1; it can be noted, that all alloys resulted in relatively low $\mathrm{Cr}$ and $\mathrm{C}$ content; as a matter of fact, the alloys studied in this work are located near the left side corner of the C-Cr-Fe-rich corner diagram (i.e. $~ 1.5 \% \mathrm{C}$ and $\sim 5 \% \mathrm{Cr}$ ), indicated by numbers in Figure 1. In particular, samples numbered as 2-5 resulted in variations of approximately from 2 to 4 pct in Mn, 0.5 to 1.0 pct of Mo, and small variations of 0.25 to 0.5 pct of $\mathrm{Ti}$ and $\mathrm{V}$. Other chemical elements were kept approximately constant at about: 1.5 pct C, 5 pct Cr, 0.3 pct Si and 1 pct Cu (Table 1). V and Ti were missing in Sample 1 with the purpose of benchmark the lean chemistry alloy (i.e. Cr-Mo alloy).

Optical microscopy was employed to analyze the microstructure. Beraha's solution was used for etching all specimens. The volume fraction of the carbides was determined using quantitative metallographic by image analyzer. Samples were analyzed by scanning electron microscopy (SEM) and X-ray diffraction (XRD). Rockwell C hardness testing and microhardness HV (300 g @ 15 s) were applied in the as-cast condition.

Small-scale pilot-plants have been recently introduced in order to perform abrasive wear testing on mill balls, such as those employed in industrial plants. The advantage of using a small-scale pilot-plant ball mill for testing materials over standard wear tests is that some parameters (related to industrial application) can be simulated under laboratory conditions and can be directly correlated to ball consumption [21].

A pilot-plant ball-mill having a total capacity of $10 \mathrm{l}$ was utilized in this research in order to evaluate the abrasive wear behavior. The pilot plant is set with a batch of $2.4 \mathrm{~kg}$ of mill-balls of $52 \mathrm{~mm}$ in diameter. During the tests the pilot-plant was set up to $97 \mathrm{rpm}$, corresponding to $90 \mathrm{pct}$ of the critical speed, the average relative position of the balls within the mill is illustrated in Figure 2. Several batches containing $2 \mathrm{~kg}$ of ore were ground during periods of 24 hours. Samples of homogenized ore of less than $12.7 \mathrm{~mm}$ in size, fed the pilot-plant ball-mill. Crushed materials of the ore sampling from the supplier (mine) was analyzed by XRD; thus, silicon oxide (quartz); aluminum-hydro-silicate, smectite-kaolinite (feldspar); calcium oxide (calcite), silver, iron, copper and gold traces were found. The tests were performed according to the following steps: "run-in", the balls were subjected to abrasive wear during $24 \mathrm{~h}$ within the pilot-plant ball mill, in fact, in this step actually rush scales and other defects from the surface are removed; grinding, periods of 24 up to $120 \mathrm{~h}$ of total grinding time were established. At the end of each grinding period, the mill was unload and re-loaded with fresh ore. Weighing; at the end of each grinding period, the mill was unload and the balls were cleaned and weighed, the weight loss of the balls gave a "benchmark" in order to predict the life of each ball.

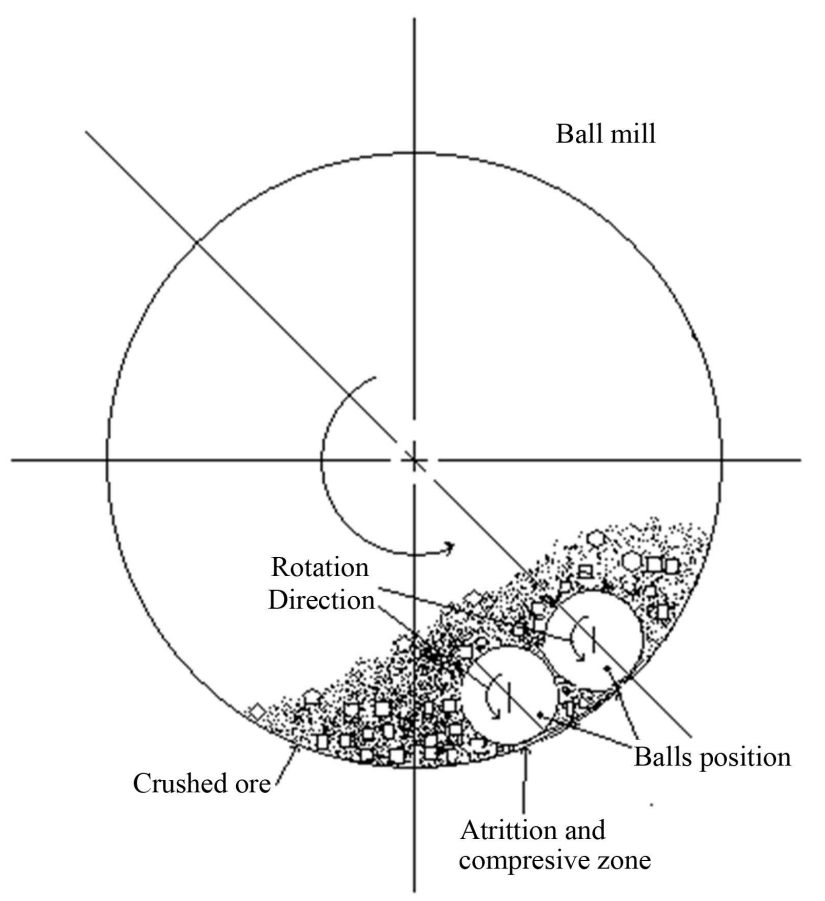

Figure 2. Position the balls within the mill. 
Table 1. Chemical composition of the cast alloys.

\begin{tabular}{|c|c|c|c|c|c|c|c|c|c|c|}
\hline \multirow{2}{*}{ Sample No. } & \multicolumn{10}{|c|}{ Weight percent } \\
\hline & $\mathrm{C}$ & Mn & $\mathrm{Si}$ & $\mathrm{Cr}$ & Mo & $\mathrm{V}$ & $\mathrm{Ti}$ & $\mathrm{Cu}$ & S & $\mathrm{P}$ \\
\hline 1 & 1.866 & 3.596 & 0.252 & 4.050 & 1.210 & - & - & 0.937 & 0.048 & 0.031 \\
\hline 2 & 1.507 & 3.593 & 0.252 & 5.741 & 0.710 & 0.224 & 0.234 & 0.932 & 0.040 & 0.041 \\
\hline 3 & 1.65 & 1.536 & 0.503 & 7.974 & 0.182 & 0.475 & 0.523 & 0.839 & 0.035 & 0.043 \\
\hline 4 & 1.735 & 3.458 & 0.252 & 5.057 & 1.234 & 0.582 & 0.561 & 0.924 & 0.052 & 0.022 \\
\hline 5 & 1.85 & 1.897 & 0.301 & 5.883 & 0.300 & 0.271 & 0.267 & 0.834 & 0.040 & 0.052 \\
\hline
\end{tabular}

\section{Results and Discussion}

\subsection{Microstructure and Hardness Analysis}

Figure 3(a) shows that microstructure of Sample 1 is comprised of dendritic matrix structure along with a homogeneous distribution of eutectic carbides. Detailed observations made on the microstructure of Sample 1 actually revealed characteristic honeycomb ledeburite morphology of eutectic carbides (Figure 3(b)).

Microstructure of Samples 2 to 5 is illustrated in Figures 4(a)-(d). The primary phase in all alloys is comprised of dendritic morphology and eutectic plate-like carbides located at the inter-dendritic spacing (i.e. Figures 4(a)-(d)). According to Figures 4(a)-(d), a finer primary microstructure is revealed in Sample 3 (see Figure 4(b)) in comparison to other samples; in addition, a homogeneous distribution of carbide regions is clearly observed in Sample 3.

According to SEM observations in Figure 5, the microstructure of Sample 1 clearly revealed the morphology of eutectic carbides of ledeburite type (i.e. $\mathrm{M}_{3} \mathrm{C}, \mathrm{M}_{7} \mathrm{C}_{3}$ ), along with scarce amount of molybdenum carbides $\left(\mathrm{Mo}_{2} \mathrm{C}\right)$ embedded within a martensite matrix $\left(\alpha^{\prime}\right)$. Further, there was no presence of titanium and vanadium carbides in Sample 1.

In contrast, the microstructure of Sample 3 (Figure 6) is composed of plate-like eutectic carbides with higher fraction of $\mathrm{M}_{7} \mathrm{C}_{3}$, further accompanied of small carbides of vanadium-titanium (V-Ti)C, and a fraction of molybdenum carbides $\left(\mathrm{Mo}_{2} \mathrm{C}\right)$. Correspondingly, a fibrous martensitic matrix $\left(\alpha^{\prime}\right)$ and small fraction of retained austenite and twinned martensite is revealed.

XRD diffractograms of the studied alloys are observed in Figure 7. According to XRD results, observed phases in both cast alloys (Samples 1 and 3) corresponded to: interdendritic eutectic carbides of $\mathrm{M}_{7} \mathrm{C}_{3}-\mathrm{M}_{3} \mathrm{C}$, $\mathrm{Mo}_{2} \mathrm{C}$ carbides, and a primary phase corresponding to martensite $\left(\alpha^{\prime}\right)$. Particularly, Sample 3 was confirmed with presence of $(\mathrm{V}-\mathrm{Ti}) \mathrm{C}$ carbides. Based on XRD results, the formation of carbides is a combination of $\mathrm{M}_{7} \mathrm{C}_{3}$ surrounded by $\mathrm{M}_{3} \mathrm{C}$ type [11] [12].

Figure 8 shows Rockwell hardness and Vickers microhardness results. Sample 3 resulted in higher values of hardness compared to that obtained in Sample 1. Higher hardness values obtained in Sample 3 are consistent to the refined primary microstructure (Figure 4(b)), the type and fraction of carbides and the presence of twinned martensite.

It is clear that plate-like morphology of $\mathrm{M}_{7} \mathrm{C}_{3}$ carbides observed in Sample 3, influenced on the elevated hardness; besides, the higher percentage of $\mathrm{Cr}$ (i.e. Table 1) actually promoted larger volume fraction of $\mathrm{M}_{7} \mathrm{C}_{3}$ carbides in Sample 3. Additionally, $\mathrm{V}$ and Ti content (Table 1), further helped to refine the martensitic microstructure as well as to increase the measurable hardness owe to formation of (V-Ti)C [10] [22]. It has been reported that $\mathrm{M}_{7} \mathrm{C}_{3}$ carbides have shown higher measurable hardness when compared to honeycomb ledeburite $\mathrm{M}_{3} \mathrm{C}$ carbides [10].

\subsection{Wear Analysis}

Abrasive wear resistance (weight lost) of all samples analyzed in this research is plotted against grinding time, as indicated in Figure 9. According to Figure 9; reduced wear resistance is observed in Sample 1 (owed to weight lost) in the full range of grinding time. In comparison, Samples 2, 4 and 5 resulted in acceptable wear performance. On the other hand, enhanced wear behavior was revealed in Sample 3. 

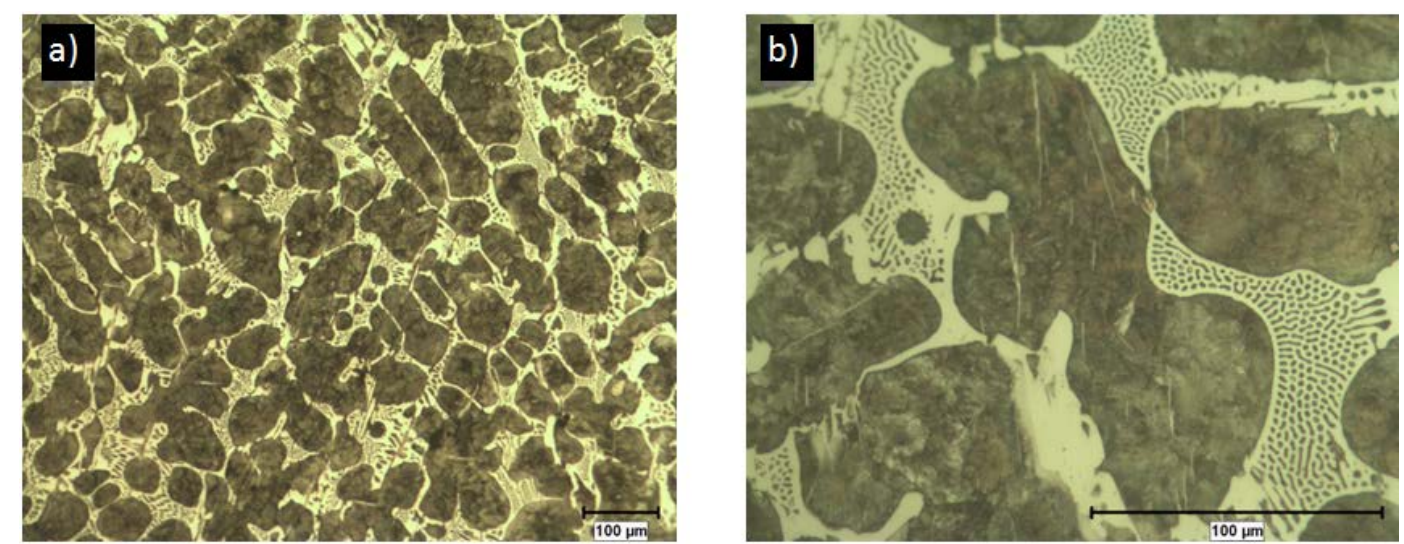

Figure 3. (a) Optical micrographs showing the microstructure of Sample 1; (b) Detailed microstructure depicting a dendritic matrix along with eutectic carbides at the interdendrític spacing.
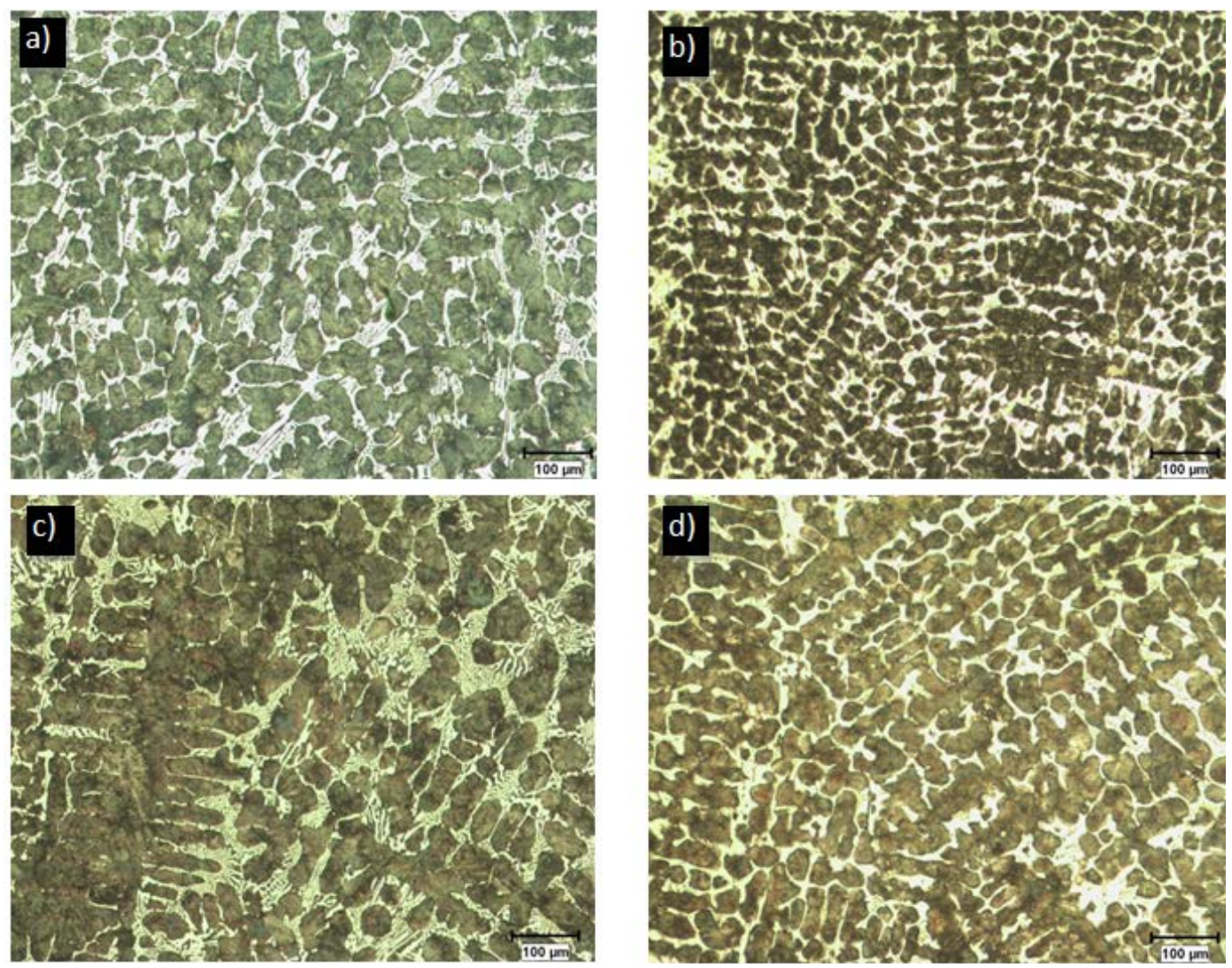

Figure 4. Optical microscope images showing the microstructure of the different cast alloys having a dendritic structure along with eutectic-carbides at the interdendritic spacing for: (a) Sample 2; (b) Sample 3; (c) Sample 4; (d) Sample 5.

Based on the above mentioned results (Figure 9); improved abrasive wear resistance is observed in Sample 3. It is clear that the higher fraction of plate-like carbides of the type $\mathrm{M}_{7} \mathrm{C}_{3}$, the grain refinement (Figure $4(\mathrm{~b})$ ), and the elevated hardness values in Figure 8, influenced on the enhanced wear behavior of Sample 3; besides, wear behavior improvement is well supported by the presence of $(\mathrm{V}-\mathrm{Ti}) \mathrm{C}$ carbides. On the other hand, reduced resistance to abrasive wear found in Sample 1; corresponded to presence of honeycomb ledeburite phase within the cast alloy as well as the lowered hardness (Figure 8).

Figure 10(a) shows a cross-section obtained along the worn area in Sample 1. Cracking across the bulk car- 


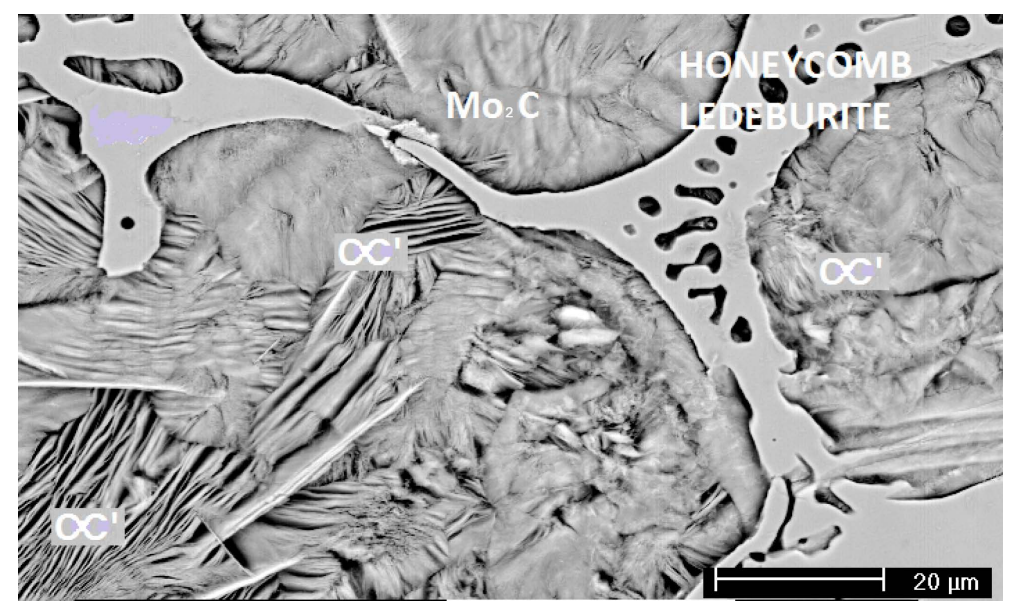

Figure 5. SEM micrographs showing the microstructure of Sample 1: carbides of $\mathrm{Mo}_{2} \mathrm{C}$, along with ledeburitic structure, with $\mathrm{M}_{7} \mathrm{C}_{3}$ carbides and martensite.

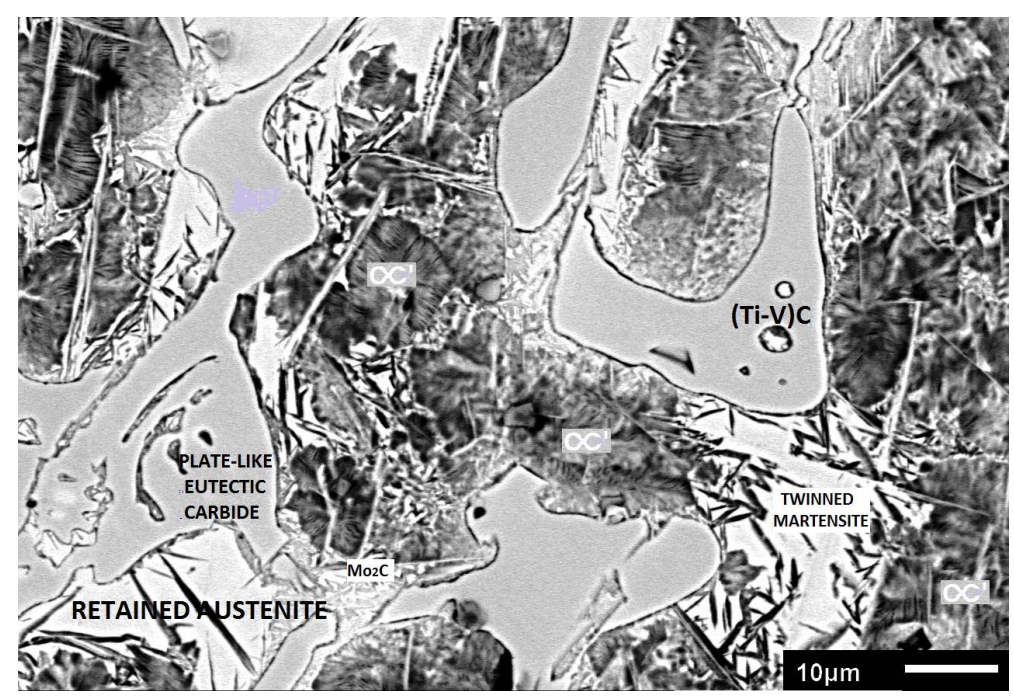

Figure 6. SEM image showing the microstructure of Sample 3: an austenite matrix, fine needles of $(\mathrm{Si}, \mathrm{Mo})_{2} \mathrm{C},(\mathrm{V}-\mathrm{Ti}) \mathrm{C}, \mathrm{M}_{7} \mathrm{C}_{3}$ and twinned martensite.

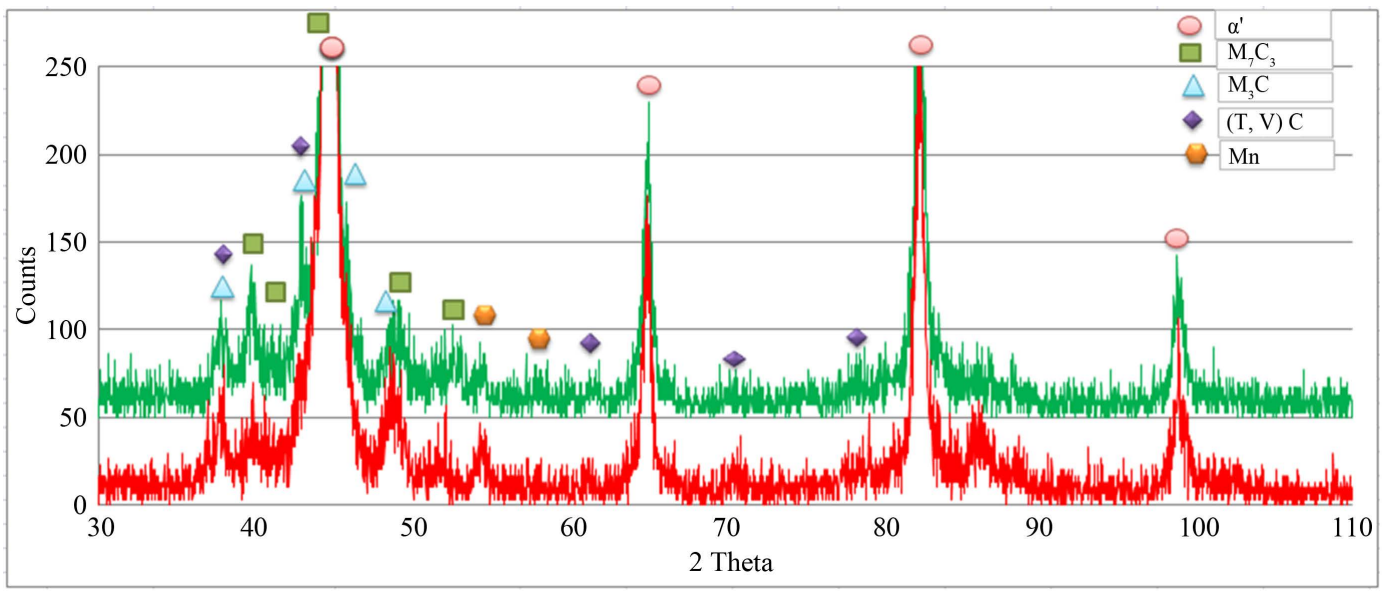

Figure 7. Diffractograms superimposed on Sample 3 (upper green line) to 1 (lower red line). 


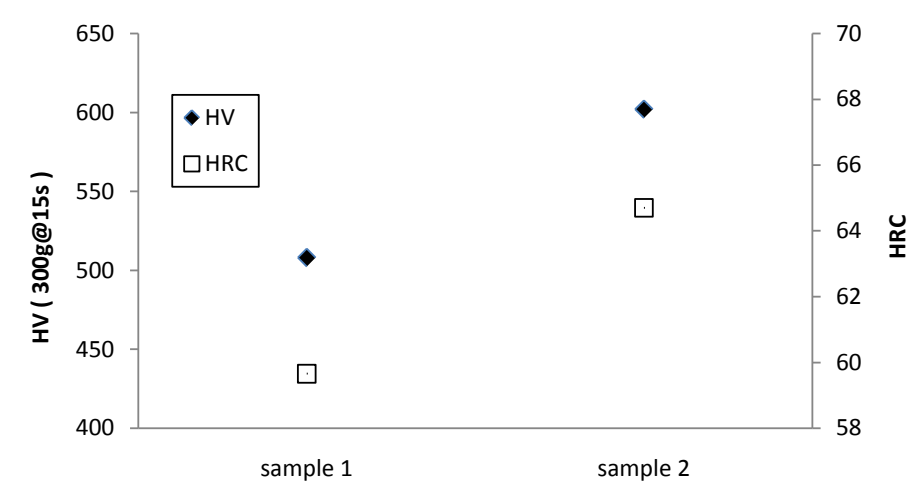

Figure 8. Rockwell hardness (HRC) and microhardness vickers (HV) results for Sample 1 (darker point) and Sample 3 (whiter point).

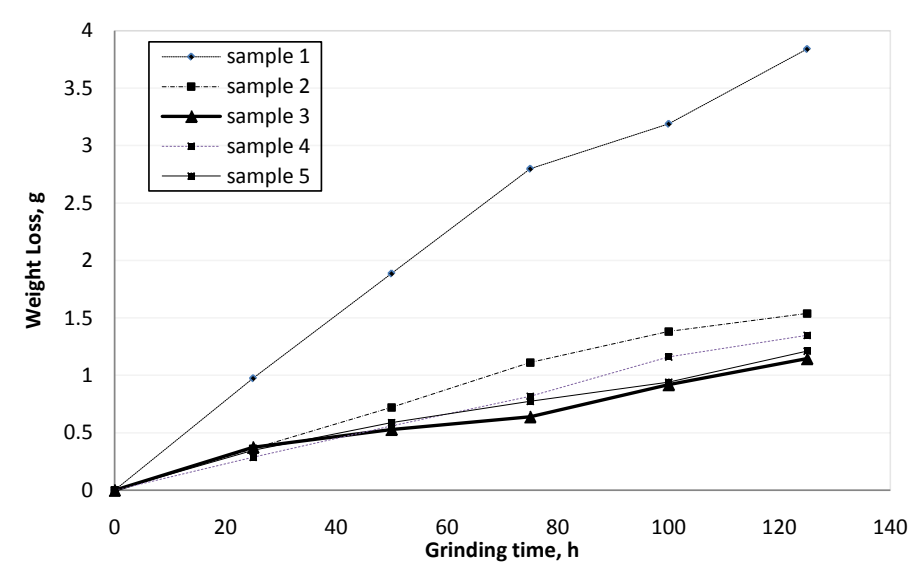

Figure 9. Abrasive wear rate of all samples.
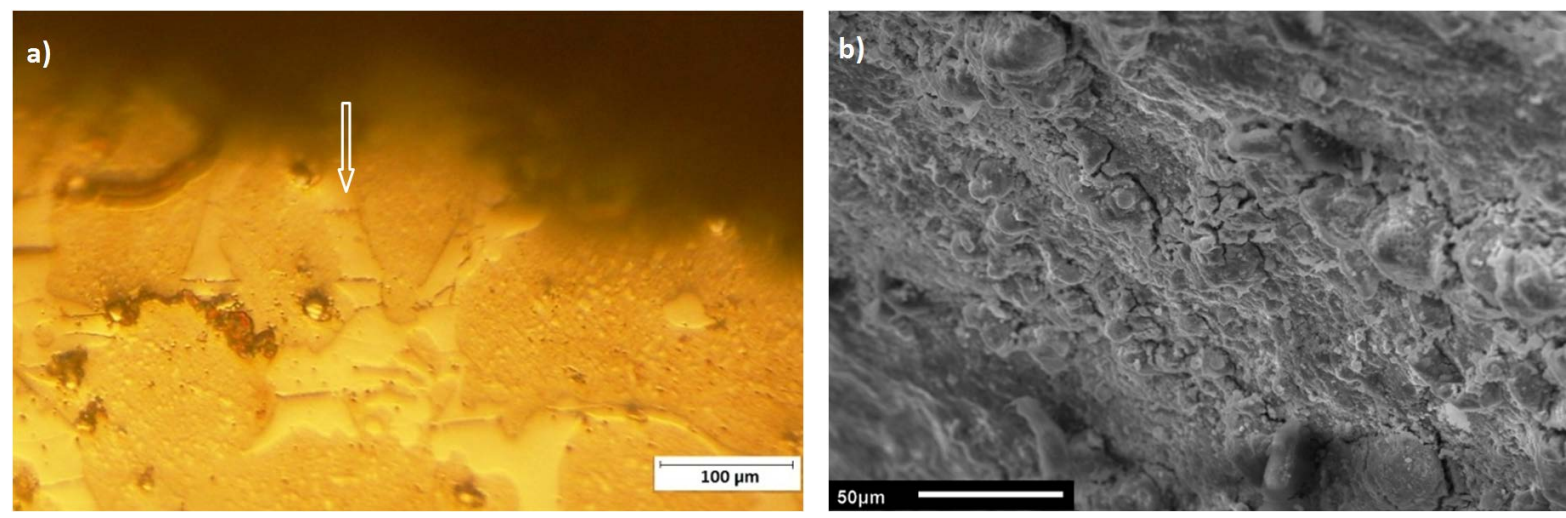

Figure 10. (a) Optical micrograph depicting the cross-section of the wore area in Sample 1; showing carbide cracking; (b) Fractography analysis indicating fatigue failure mechanism along the sub surface.

bide is clearly seen in Figure 10(a) (as indicated by the arrow). Further analysis made through fractography (Figure 10(b)) showed cracking along the subsurface accompanied by a significant amount of delamination owed to maximum stresses generated underneath the surface. In fact, cracks nucleate and propagate under the surface thus fragmenting later. According to the above mentioned, fatigue mechanism is developed and can be stated as the main wear mechanism.

On the other hand, Figure 11(a) confirmed similar wear mechanism occurring in Sample 3; thus, carbide cracking along with a random location of cracks along the matrix is observed in Figure 11(b). According to the above mentioned, it might be inferred that the predominant wear mechanism in Sample 3 is fatigue. However, 

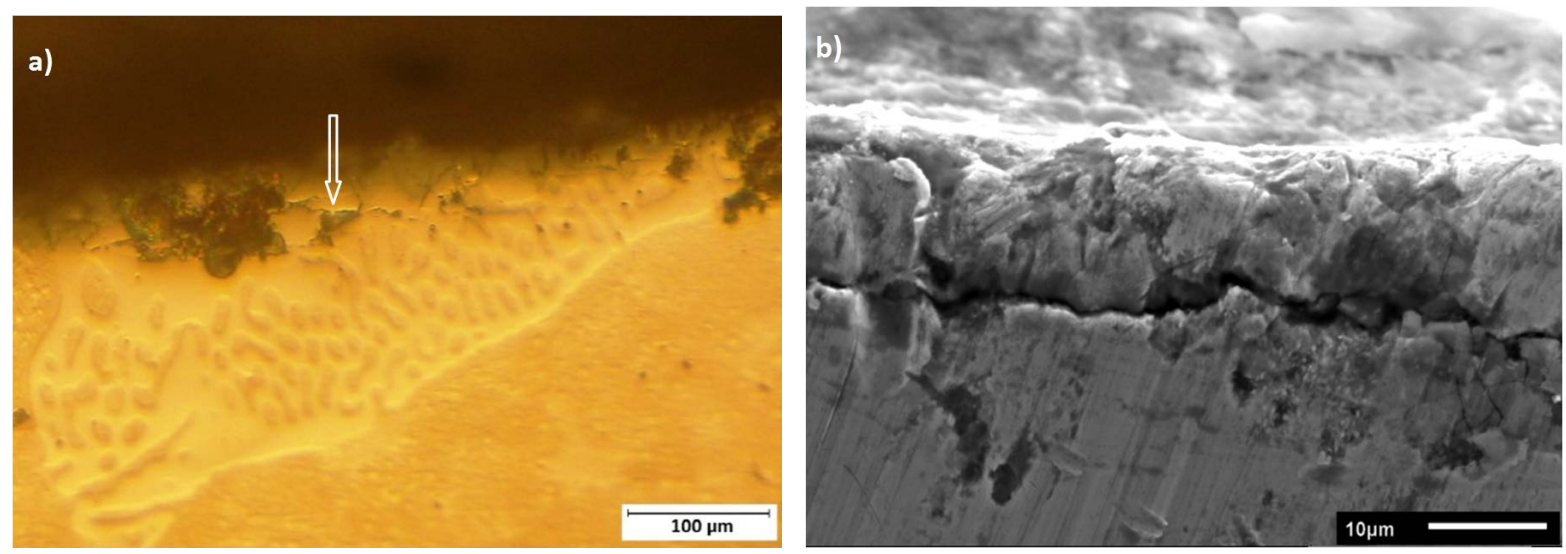

Figure 11. (a) Optical micrograph depicting the cross-section of the wore area in Sample 3 indicting carbide cracking; (b) fractography analysis in Sample 3 indicting fatigue failure mechanism along the subsurface.

delamination was not observed in Sample 3 due to the type of carbides and the refined primary matrix, thus enhancing wear resistance. Carbide cracking in martensitic matrix cast iron balls has been also reported [1].

Based on the above results, honeycomb ledeburitic microstructure resulted in reduced hardness in Sample 1 (see Figure 8) in comparison to higher hardness in $\mathrm{M}_{7} \mathrm{C}_{3}$ and $\mathrm{M}_{3} \mathrm{C}$ carbides type in Sample 3. It has been reported that chromium carbide $\left(\mathrm{M}_{7} \mathrm{C}_{3}-\mathrm{M}_{3} \mathrm{C}\right)$ present higher hardness in comparison to cementite $\left(\mathrm{M}_{3} \mathrm{C}\right)$, thus resulting in good abrasion resistance for those materials [10] [23].

Additions of V and Ti seemed to refine the microstructure in Sample 3 (Figure 4(b)). Vanadium is a strong carbide-forming element if contained in the range $0.1 \%$ to $0.5 \%$ and is commonly found to form primary and secondary carbides when combined with iron, increasing hardness with V content [10]. Likely, the effect of Ti (in the composition up to $0.38 \%$ ) is to improve abrasion resistance owe to formation of TiC [22]. Hereby, a combination of massive $\mathrm{M}_{7} \mathrm{C}_{3}$ and the presence of relatively fraction of $(\mathrm{V}-\mathrm{Ti}) \mathrm{C}$ was highly influencing on the resultant improved wear resistance of low $\mathrm{Cr}$ white cast irons.

\section{Conclusions}

1) Honecomb ledeburitic $\left(\mathrm{M}_{3} \mathrm{C}\right)$ microstructure along with the scarce amount of molybdenum carbides $\left(\mathrm{Mo}_{2} \mathrm{C}\right)$ embedded within a martensite matrix of the studied mill balls resulted in reduced abrasion wear resistance.

2) Improved wear resistance in cast steels mill balls was influenced by the higher fraction of plate-like carbides of the type $\mathrm{M}_{7} \mathrm{C}_{3}$, the refined martensitic matrix, as well as the elevated measurable hardness.

3) It was found that additions of $\mathrm{Ti}$ and $\mathrm{V}$ helped on the refinement of the martensitic matrix as well as on the formation of (V-Ti)C carbides, which in turn, influenced on the elevated hardness and the resultant wear behavior.

\section{Acknowledgements}

The authors acknowledge the assistance of Mr. Ing. Maximino Burgos, grinding balls seller in Mexico, for his contributions to the discussion of the chemical composition. The authors would like to acknowledge FomixConacyt, México; for sponsoring this research.

\section{References}

[1] Albertin, E. and Sinatora, A. (2001) Effect of Carbide Fraction and Matrix Microstructure on the Wear of Cast Iron Balls Tested in a Laboratory Ball Mill. Wear, 250, 492-501. http://dx.doi.org/10.1016/S0043-1648(01)00664-0

[2] Čikara, D., Rakin, M. and Todić, A. (2009) Cast Steel-SiC Composites as Wear Resistant Materials. FME Transactions, 37, 151-155.

[3] Studnicki, A., Kilarski, J., Przybył, M., Suchoń, J. and Bartocha, D. (2006) Wear Resistance of Chromium Cast IronResearch and Application. Journal of Achievements in Materials and Manufacturing Engineering, 16, 63-73.

[4] Rajagopal, V. and Iwasaki, I. (2006) Corrosion Properties of Cast Iron Ball Materials in Wet Grinding. Corrosion, 48, 
124-131. http://dx.doi.org/10.5006/1.3299818

[5] Chenje, T.W., Simbi, D.J. and Navara, E. (2004) Relation between Microstructure, Hardness, Impact Toughness and Wear Performance of Selected Grinding Media for Mineral Ore Milling Operations. Materials \& Design, 25, 11-18. http://dx.doi.org/10.1016/S0261-3069(03)00168-7

[6] Sampathkumaran, P., Seetharamu, S., Ranganathaiah, C., Raj, J.M., Pujari, P.K., Maheshwari, P., Dutta, D. and Kishore (2011) Surface and Bulk Defects in Cr-Mn Iron Alloy Cast in Metal and Sand Moulds: Characterization by Positron Annihilation Techniques. Journal of Surface Engineered Materials and Advanced Technology, 1, 136-143. http://dx.doi.org/10.4236/jsemat.2011.13021

[7] Atabaki, M.M., Jafari, S. and Abdollah-Pour, H. (2012) Abrasive Wear Behavior of High Chromium Cast Iron and Hadfield Steel—A Comparison. Journal of Iron and Steels Research, 19, 43-50. http://dx.doi.org/10.1016/S1006-706X(12)60086-7

[8] Weber, K., Regener, D., Mehner, H. and Menzel, M. (2001) Characterization of the Microstructure of High-Chromium Cast Irons Using Mösbauer Spectroscopy. Materials Characterization, 46, 399-406. http://dx.doi.org/10.1016/S1044-5803(01)00143-7

[9] Thorpe, W.R. and Chicco, B. (1993) The Fe-Rich Corner of the Metastable C-Cr-Fe Liquidus Surface. Metallurgical Transactions A, 24, 981-988.

[10] Breyer, J.P. and Walmag, G. (2002) Metallurgy of High Chromium-Molybdenum White Iron and Steels Rolls. Rolls for the Metalworking Industries-ISS, Warrendale, 29-40.

[11] Schon, C.G. and Sinatora, A. (1998) Simulation of Solidification Paths in High Chromium White Cast Irons for Wear Applications. Calphad, 22, 437-448. http://dx.doi.org/10.1016/S0364-5916(99)00003-6

[12] Hugget, P. and Ben-Nissan, B. (2007) Development of a Low Melting Point White Cast Iron for Use in Composite Alloy Manufacture. Materials Forum, 31, 16-23.

[13] Agunsoye, J.O., Isaac, T.S. and Abiona, A.A. (2013) On the Comparison of Microstructure Characteristics and Mechanical Properties of High Chromium White Iron with the Hadfield Austenitic Manganese Steel. Journal of Minerals and Materials Characterization and Engineering, 1, 24-28. http://dx.doi.org/10.4236/jmmce.2013.11005

[14] Agunsoye, J.O., Aigbodion, V.S. and Sanni, O.S. (2011) Effect of Heat Treatment on Microstructure and Mechanical Properties of NF6357A Cast Alloy for Wear Resistance Application. Journal of Minerals \& Materials Characterization \& Engineering, 10, 1077-1086.

[15] Albertin, E.B. and Sinatora, A. (2001) Effect of Carbide Fraction and Matrix Microstructure on the Wear of Cast Iron Balls Tested in a Laboratory Ball Mill. Wear, 250, 492-502. http://dx.doi.org/10.1016/S0043-1648(01)00664-0

[16] Dogan, O.N., Laird II, G. and Hawk, J.A. (1995) Abrasion Resistance of the Columnar Zone in High Cr White Cast Irons. Wear, 181-183, 342-349. http://dx.doi.org/10.1016/0043-1648(95)90041-1

[17] Dogan, O.N. (1996) Columnar to Equiaxed Transition in High Cr White Iron Castings. Scripta Materialia, 35, 163168. http://dx.doi.org/10.1016/1359-6462(96)00110-8

[18] Maldonado-Ruiz, S.I., Lopez, D., Velasco, A. and Colas, R. (2004) Microstructural Evaluation of Wear Resistant High Chromium, High Carbón Cast Irons. Materials Science and Technology, 20, 393-398. http://dx.doi.org/10.1179/026708304225012224

[19] Maldonado-Ruíz, S.I., Martínez, D.I., Velasco, A. and Colás, R. (2005) Wear of White Cast Irons by Impact of Direct Reduced Iron Pellets. Wear, 259, 361-366. http://dx.doi.org/10.1016/j.wear.2005.02.061

[20] (2010) Design-Ease 7.1, Stat-Ease, Inc ${ }^{\mathrm{TM}}$.

[21] Albertin, E. and De Moraes, S.L. (2007) Maximizing Wear Resistance of Balls for Grinding of Coal. Wear, 263, $43-47$. http://dx.doi.org/10.1016/j.wear.2007.02.013

[22] Arikan, M.M., Cimenoglu, H. and Kayali, E.S. (2001) The Effect of Titanium on the Abrasion Resistance of 15Cr-3Mo White Cast Iron. Wear, 247, 231-235. http://dx.doi.org/10.1016/S0043-1648(00)00523-8

[23] Werquin, J.C. and Caillard, J.C. (1988) New Vertically Spum Cast Rolls for Hot and Cold Rolling and Their Ability to Satisfy the New Demands of Current Rolling Practices. 30th MWSP Conference Proceedings, 26, 311-336. 
Scientific Research Publishing (SCIRP) is one of the largest Open Access journal publishers. It is currently publishing more than 200 open access, online, peer-reviewed journals covering a wide range of academic disciplines. SCIRP serves the worldwide academic communities and contributes to the progress and application of science with its publication.

Other selected journals from SCIRP are listed as below. Submit your manuscript to us via either submit@scirp.org or Online Submission Portal.
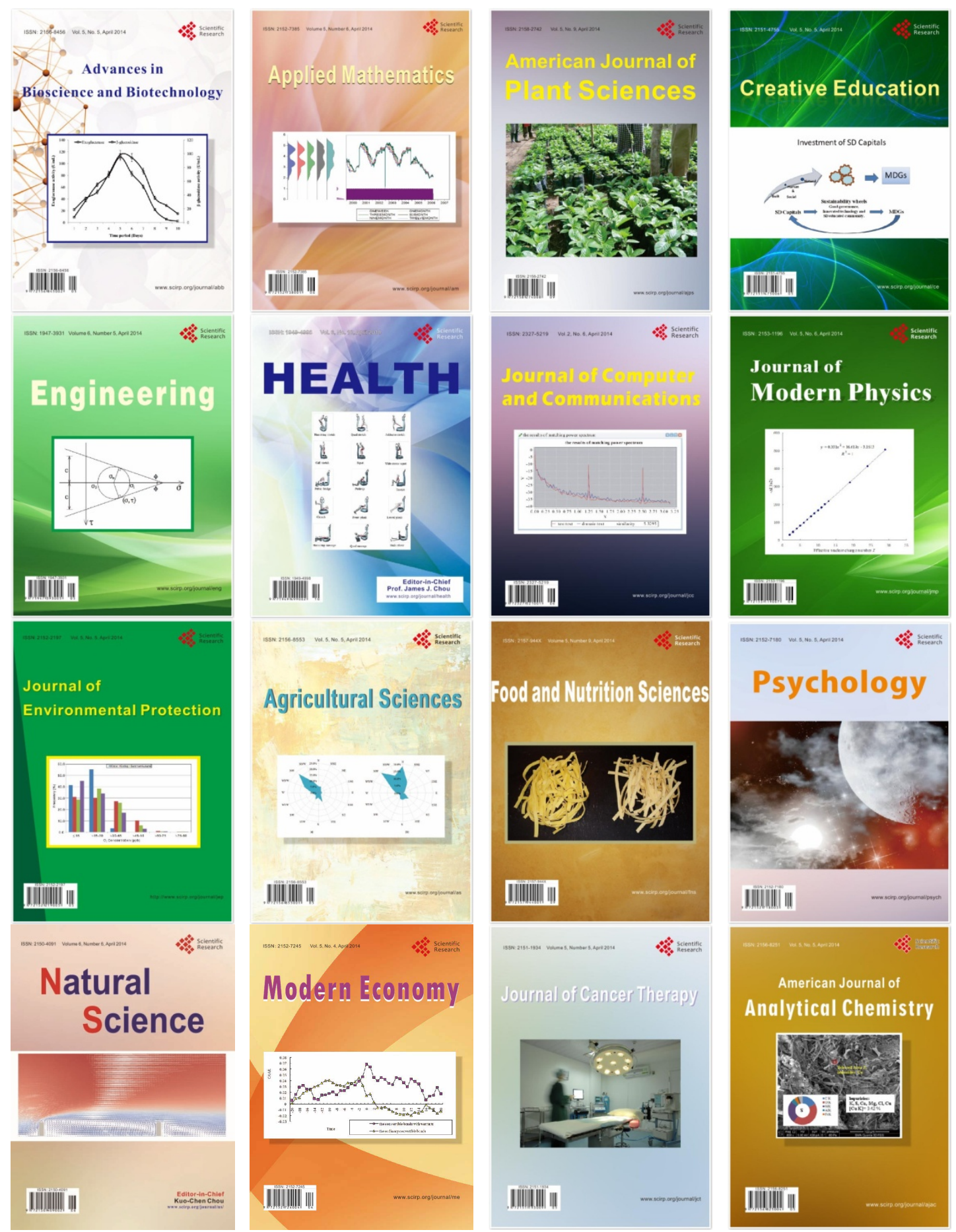